\title{
The role of physical therapists in the context of family health support centers
}

\author{
Atuação do fisioterapeuta no contexto dos \\ núcleos de apoio a saúde da família
}

\author{
Cássia Cristina Braghini, Fátima Ferretti, Lucimare Ferraz*
}

Universidade Comunitária da Região de Chapecó (Unochapecó), Chapecó, SC, Brazil

\begin{abstract}
Introduction: Since 2008, with the establishment of Family Health Support Centers (NASF), physiotherapists have been listed among professionals to be included in the team. Physical therapists have many assignments in the NASF, which are conducted through group sessions, in the households, with complementary and integrative practices, lectures and referrals to reference services. Objective: To analyze role and obstacles to the realization of the work of the physiotherapists in NASF. Methods: This is a qualitative research, guided by the case study method. The population was composed by eight physiotherapists active in NASF. Participant observation and semi-structured interviews with physiotherapists were used for data collection. Results: The actions performed by physiotherapists consist of group assistance, home visits, ear therapy and oxygen therapy and activities of health education and disease prevention. As for the barriers, these included lack of training to work at NASF; structural and organizational impediments; insufficient workload and fragility of professional training to work with public health. Conclusion: The role of physiotherapists is in line, in part, with the guidelines recommended by NASF, but principles as matrix support and collective pacts need to be strengthened.
\end{abstract}

Keywords: Primary Health Care. Physiotherapy. Family Health.

\footnotetext{
* CCB: MS, e-mail: cafisio@unochapeco.edu.br FF: PhD, e-mail: ferrettifisio@yahoo.com.br LF: PhD, e-mail: lferraz@unochapeco.edu.br
} 
Resumo

Introdução: Desde 2008 com a implantação dos Núcleos de Apoio a Saúde da Família (NASF), o fisioterapeuta foi relacionado como profissional a ser incluído na equipe. São inúmeras as atribuições do profissional no $N A S F$, as quais são realizadas por meio de atendimentos em grupo, no domicilio, com práticas integrativas e complementares, palestras e encaminhamentos para serviços de referência. Objetivo: Analisar a atuação do fisioterapeuta e os entraves para a realização do seu trabalho no NASF. Métodos: Pesquisa qualitativa, sob a orientação do método estudo de caso. A população de estudo foi composta por oito fisioterapeutas em atuação no NASF. Para coleta de dados foi utilizada a observação-participante e entrevista semiestruturada com os fisioterapeutas. Resultados: As ações realizadas pelos fisioterapeutas consistem de atendimentos em grupos, visitas domiciliares, auriculoterapia e oxigenoterapia e atividades de educação em saúde e prevenção de enfermidades. Quanto aos entraves, observou-se falta de capacitação para trabalhar no NASF, impedimentos estruturais e organizacionais, carga horária insuficiente e fragilidade na formação quanto à saúde pública. Conclusão: A atuação do fisioterapeuta atende, em parte, o preconizado pelas Diretrizes do NASF, porém, alguns princípios como o apoio matricial e a pactuação coletiva precisam ser fortalecidos.

Palavras-chave: Atenção Primária à Saúde. Fisioterapia. Saúde da Família.

\section{Introduction}

Since the origin of the Physical Therapy as profession, this has been linked to the tertiary level of health care. However, with the creation of the Unified Health System (SUS) and the organizational redefinition of assistance through the Family Health Strategy (FHS) in 1997, Physical therapy went on to discuss and expand is field with a view to contribute to the realization and consolidation of primary care.

The inclusion of physiotherapists in primary care is recent. Although part of some family health teams, it was only in 2008 with the establishment of Family Health Support Centers (NASF) that physiotherapists were included in multidisciplinary teams.

NASF guidelines mention the specific role of physiotherapists only concerning the preparation for humanized childbirth. Yet, they also list assignments that are common to all professionals in the center, such as identification based on the diagnosis of the territory where activities are to be developed; reception of users and humanization of care; intersectoriality; health promotion; social participation; among others (1).

Authors have reported experiences of actions of physiotherapists integrated to FHS or NASF teams with service groups, complementary and integrative practices, home care, lectures and referrals to reference services (2 - 4). Nascimento et al. (5) highlight also the performance of physiotherapists in basic care with the elderly through individual visits, physical activities, body practice of Traditional Chinese Medicine and educational groups, pointing out that after interventions, participants improved physical and functional aspects and expanded the family and community living.

Miranda (6) added that physiotherapists in NASF can contribute to the development of health actions that go beyond rehabilitation through the prioritization of collective action, recognition of the needs of individuals and families, creation of links and action in conjunction with the multidisciplinary team.

On the other hand, authors consider that the inclusion of physiotherapy in primary care is an ongoing process and still presents difficulties of performance. These include the low workload, lack of resources and professionals, difficulty that users have to access this service, and training based on a model that values the tertiary level of assistance $(2,4,7)$.

Thus, the insertion of the physiotherapist in primary care through NASF is recent and the work still faces difficulties. Moreover, Neves and Aciole (8) conducted a systematic review of the role of physiotherapists in the family health team and found that there is a reduced number of publications that deal with this topic. To contribute to the discussion of this problem, the present study aimed to characterize the professional profile and to analyze the actions, positive aspects and difficulties to the practice of 
physiotherapists in the context of NASF in a municipality of western Santa Catarina.

\section{Methods}

This study was developed from a qualitative perspective, guided by the case study method in the period between August and November 2013. The research project that originated this study was approved by the Research Ethics Committee of Unochapecó under the Protocol no 044/13.

The study context was represented by a municipality in the state of Santa Catarina that has four type $1 \mathrm{NASF}$, each with 9 to 12 family health teams active in the territory. At the time of data collection, there were eight physiotherapists working in the four NASF, twenty hours per week. These physiotherapists represented the study population.

NASF have the modalities 1, 2 and 3. The NASF 1 is linked and offer support to a minimum of five and a maximum of nine family health teams and/or $A B$ teams for specific populations. In the case of NASF 2 , each one is linked to at least three and no more than four family Health Teams and/or AB Teams, while NASF 3 is linked to one or two Family Health Teams and/or $A B$ teams.

Physiotherapists were personally contacted in a team meeting where all professionals were gathered and the objectives and methodology of the study were explained. Those who agreed to participate signed a Informed Consent form.

Data collection included the application of a questionnaire to evaluate the profile of professionals and participant observation of the activities developed by the eight NAS physiotherapists in two shifts and in different territories, monitored by the professional, guided by a script for observation and recorded in a field notebook. In total, physiotherapists were followed by the same observer for sixteen shifts and about sixty-four hours.

In addition, three physiotherapists from different NASF were interviewed by the same researcher, who agreed to come in a previously scheduled time and place. For this, we used the method of semistructured interview guided by a script with guiding questions, and speeches were recorded with a digital recording device. After transcription of reports, these were sent by e-mail to the participants to validate the data.
Thematic content analysis was used for analysis, which is characterized by pre-analysis, exploration of material, treatment of results and interpretation (9). In order to preserve the anonymity of individuals, they were identified through codes C1, C2 and C3.

\section{Results and discussion}

On the profile of physiotherapists of this study, it was found that the average age was 25.8 years, representing a young population, and most of them were women. These data are similar to the age and gender group cited in the literature as the profile of this professional category $(10,11)$.

After analyzing the interviews and observations, analytical categories on the activities that these professionals develop in the NASF work context emerged. First, the actions developed by physiotherapists will be explained. Then, the barriers experienced by these professionals will be explored.

Actions developed by physiotherapists in the NASF

According to the physiotherapists, group consultation is part of the actions developed by them in NASF:

What I do, is weekly groups, once a week. (P1)

I work with groups of bodily practices. (P3)

I give assistance to groups at the community park, and then I use the instruments to the elderly, outdoors. (P2)

I give lectures and integrative activities in the unit groups, to hypertension, diabetes patients. (P1)

With participant observation, it was found that group assistance is part of the routine of the physiotherapists in NASF and these consist in moments of exercises and guidelines. The target population of these group activities is pregnant women, workers and people with degenerative changes of the spine. The physiotherapists use Pilates and Liam Gong exercises, which indicates that the organization of groups is driven by the demand of people in need of rehabilitation. Some groups have the participation of other members of NASF such as physical 
trainers and nutritionists, who develop activities together with the physiotherapist. Participants of these groups are referred by the physiotherapists in moments of individual evaluation or by other NASF and FHS professionals.

Group assistance are also evidenced in the literature as the duty of the physiotherapists in primary care $(2,12,4)$. The ordinances and programs related to public and collective health practices under primary health care in Brazil also favor group actions. This approach enhances the communication between professionals and users, since the relationship between the two is narrowed, and is better if compared to an individual consultation (13).

Portes et al. (14) conducted a literature review on the role of physiotherapists in primary care and also showed that group activities are present in their practices. However, they pointed out that the presence of a disease becomes criteria for inclusion, characterization and even choice of the name of the groups, evidencing the presence of the traditional care model and poor approach to health promotion.

The NASF proposal seeks to eliminate this traditional model and the fragmentation of care, since it considers the individual in his entirety, that is, in his social, family and cultural context. We observed in the context studied that physiotherapists still work, even when collectively, with users that have functional skeletal muscle changes or diseases and carry out preventive actions based on the underlying pathology. This situation can be explained by the high demand of users seeking NASF physiotherapists when they are already affected by the disease and, therefore, for a rehabilitation treatment. This, in part, may hinder the organization of health promotion activities with healthy subjects, since, the professionals are focused in assisting patients that need more attention, reinforcing the stigma that these professionals act focused on tertiary care.

The law that created the roles NASF members in the municipality relates the physiotherapist's attributions with the necessary care to prevention and rehabilitation of health, as well as the treatment of users with acute and/or degenerative disorders and the use of Kinesiotherapy (15). Moreover, NASF Guidelines state that rehabilitation plays an important role in the centers, since the multiprofessional action can create opportunities for reducing disabilities and impairments with a view to improving the quality of life of individuals, social inclusion and to increase the access to the health care system (1).

Home visits were also highlighted as actions carried out by physiotherapists, as we can see in the following reports:

Home visits are frequently requested, so we follow the doctor and the nurse. (P2)

I make home visits when requested by the doctor, nurse or health worker and halso ome orientation to the caregivers of bedridden patients. (P1)

Home visits were also followed during the observation, especially for users with limitations to travel to the Family Health Center (FHC), with walking problems or bedridden. Visits are usually requested by members of the FHC and in one of the cases these were held in conjunction with the community health worker. During visits the physiotherapist gave guidance on prevention of deformities, decubitus ulcers and performing exercises.

Baena and Soares (16) argue that home visits along with community health workers are important due to different perceptions of professionals to identify health needs. Gonçalves (17) and Dibai Filho and Aveiro (4) consider home visits as part of the physiotherapist's role in primary care and in the view of Medeiros, Pivetta and Mayer (18), this activity has the potential to create links and to promote hosting.

Physical therapists also reported that they work with Ear therapy.

I work with ear therapy when I see a patient who can be treated by it or when the physician indicates this treatment. (P1)

Ear therapy was a practice frequently seen in circulation at the FHC office during the observations. These actions were stimulated by Ordinance $\mathrm{n}-971$, 2006, of the Ministry of Health, National Policy on Integrative and Complementary Practices, which aims at the implementation of these practices in SUS for disease prevention, promotion and restoration of health in primary care (19). The Primary Care Notebooks, which address NASF guidelines, also state that integrative and complementary practices such as acupuncture and body practices (Do-in, Liam Gong in 18 therapies, Tai Chi Chuan) represent a tool to be used by professionals (1). 
Complementary and integrative practices are seen as effective techniques for strengthening health promotion (20) and the offer of complementary and alternative medicines in the SUS may represent a strategy for the management and control of medicalization (21).

Home care with oxygen therapy was also mentioned:

I provide care using oxygen therapy. In the country side, the coordinator is grateful when anyone can help to assist these patients and guide them at the level of respiratory therapy. (P3)

The home care notebook provides regular monitoring of the physiotherapist to the users enrolled in home oxygen therapy (22), as the Ordinance no 963 of 2013 lists physiotherapist among the home care multidisciplinary team and among multidisciplinary support teams, where NASF have function to support the family health teams responsible for home care (23).

Activities related to health education and disease prevention were also mentioned:

A form of education and prevention that I see is when the patient comes to the consultation; this is the moment I have not only to evaluate, but also to guide him. You have to do this, avoid that, but if you don't avoid it, you will have a problem, I give an exercise, guidance on how to perform it at home, that sort of things. (P1)

We know that the result of a good quality of life is the change in lifestyle and perhaps, in this logical, the physical therapist may greatly contribute to health education, disease prevention. (P3)

Beyond the view of physiotherapists of this study, health promotion from the perspective of NASF does not represent only the information and training of individuals, but rather implies the understanding of professionals and teams that the ways of living of the population are products and producers of economic, political, social and cultural transformations (1). To this end, a possibility beyond the transmission of knowledge is the appreciation of popular knowledge grounded in the reality, seeking dialogue, reflection and the exchange of experiences (24).

Activities not cited by physiotherapists were noted during the observation of the work routine, such as individual assessments with aim to organize the flow of calls from users of physiotherapy, whether referring to the existing groups, or to ear therapy or clinic. There were also meetings with other FHC and NASF professionals to discuss the demands in the territory, and the weekly meetings of NASF teams for action planning.

The actions seen and reported by physiotherapists correspond largely to what is recommended by the Ministry of Health as duties of NASF professionals. However, it was noted that some actions need to be better implemented, especially the collective construction of therapeutic projects, inter-consultation and one of the key aspects in the work process of professionals that is the definition and agreement on tasks to be developed by the NASF team, the manager and the FHC team. It is important also to mention the need to strengthen some of NASF assumptions present in its Guidelines, as the knowledge of the territory, interdisciplinarity, social participation, intersectoriality and continuing education (1).

Another aspect that needs to be improved has to do with matrix support, a central element of the NASF proposal that has two support dimensions, the assistance support (direct clinical action to users) and the technical and pedagogical action, which provides educational support to the team towards knowledge sharing in the pursuit of solving the health needs of the population (1). This last dimension is the one that seems to be more fragile with respect to the role of the physiotherapist in the NASF in the city studied.

Technological tools to support management and attention such as the pact of support, Extended Clinic, Single Therapeutic Design and Health Project in the Territory have not been carried out by professionals either.

Thus, the need to develop continuing education in health services to maintain the activities that have had results and are recommended as the role of physiotherapists in NASF is evident. It is also imperative to enhance the integration between professionals and managers and the factual implementation of tools which could result in better resolution power of the actions developed.

Barriers faced to development of the work of physiotherapists in the NASF

One of the difficulties experienced by physiotherapists to develop a better quality work in NASF was the lack of training, as shown in the following reports: 
We had no specific training to work in NASF when we entered the service. I had no guidance on what to do. This was slowly figured out as demand arose and then we were organizing the work. (P1)

We do not have any training. Neither to prepare for working in the NASF nor to corporal practices. We are there with our knowledge only. (P3)

This situation mentioned by physiotherapists reveals an obstacle to their actions, as they reported they did not have training. This situation impacts on the knowledge of the organization and the foundations of services where these professionals work, causing a negative effect on their practices.

Davini (25) reports that training is one of the tactics used to address health service problems. However, in many cases, it is not possible to transfer learning to collective action. On the other hand, continuing education presents a greater potential for changes in the training of health service workers because teaching is incorporated into the daily life of organizations, and into social and work practices, from the problematization of the actions, making people reflect on and build knowledge. Continuing education is an effective strategy for the organization and transformation of health services, including NASF.

NASF professionals from a county of Rio Grande do Norte reported receiving an introductory training for their role in the center, but they still deemed this training insufficient and focused on theoretical concepts on the SUS and on primary care, but without in-depth information on matricial and enlarged clinic recommended by NASF (26).

Another obstacle cited was the structural and organizational issue, as cited in the following lines:

It is difficult to work with the group because there is no enough material, we do not have enough mattresses. If it rains, we have no place to stay. (P2).

This issue of materials is really troublesome. I have groups in which patients adhere well, have good frequency, but we have no mattresses, thus we do it standing, or in the middle of bats and whatever else appears. (P3)

During the observation, it was noted that the physical structure is one of the difficulties experienced in the daily work of physiotherapists. For example, at times, groups of several people were crowded into small rooms or did not have chairs, mattresses; there was poor ventilation and illumination.

Reis and Vieira (27) also highlighted the lack of material as an obstacle to the realization of the actions of NASF Occupational Therapists in Fortaleza (CE), pointing to bureaucracy and delay in delivery as points that prevent the practices of these professionals. However, to Souza et al. (7), this concern with scarcity of resources such as machines and equipment translates a limited view of the role of the physiotherapist, as it associates this role to an instrumental view of rationalizing health care.

As for the lack adequate space, physiotherapists claim that there is not always such space or that this is not available to them (28). This is against the Ministry of Health's recommendations on provision of infrastructure for the functioning of primary health care, such as collective activities of these professionals.

On the other hand, one guideline and also the responsibility of all NASF professionals is the development of collective actions of integration between sectors such as schools, neighborhood associations and leisure facilities with a view to intersectoriality (1). Another possibility consists in the strategies cited by NASF professionals, reported by Oliveira et al. (29), to address the lack of materials and structure, such as the use of community equipment, outdoor spaces and creativity in improvisation and adaptation of the resources available.

Besides the shortage of materials and inappropriate physical space, unavailability of vehicle for carrying out home visits was also cited, as evident in these reports:

The biggest problem is when you need to go for a visit or service in a place that is far and there is no car. The car comes only on that specific day to the unit and everything is difficult when you need a car to make a visit because you cannot book, thus, sometimes we cannot make a home visit because we have no vehicle. (P1)

I have the same difficulty because the car is there in the afternoon on Thursday and I cannot be there that day, if I need the car I will do nothing. I will do what can be done without the car. (P3)

The difficulty to make home visits due to the lack of car was also seen during the observations. This was 
seen in situations when the FHC coordinator had already scheduled the visit in advance, one week earlier, and, at the moment of leaving they noticed that the vehicle was not available. Another circumstance observed was that the physiotherapist did not find the user at home. These difficulties were also reported by NASF occupational therapists in Fortaleza (CE), where the absence or shortage of vehicles hinders the displacement of teams to perform home visits (27).

Another difficulty expressed by physiotherapists was the insufficient time to develop the work in NASF, as can be seen in these lines:

The time to do the work is too short. We have not only one unit, it's six units. We have many demands and all patients come to us to be sent to groups or to evaluation. So, one shift in each unit, this makes the work very difficult. (P2)

Few hours. Twenty hours a week you can make until noon, four hours in each unit, sometimes two half days, but this is not enough for the activities that are developed and also to address the needs that we see that are necessary. (P1)

The workload was cited by many physiotherapists as an impediment to the expansion of their actions. However, during the observation, it was seen that professionals had idle time, as in the case they were not able to make home visits and this space cannot replaced with other activity, or when they had to move to a FHC located in the country side. In these cases, a large amount of time is reserved for the round trip, and one single activity is carried out at that location, as for example, actions to only one group. Situations like these show the lack of planning of activities in order to make a better use of the time of the professional in the territory. These idle moments could be filled with activities with other FHS team professionals, with users, case studies etc.

The physiotherapist and social worker in the context of the NASF studied have different workloads from other professionals (twenty weekly hours, and not forty, as the rest). This is due, in the first case, to a law that establishes that the working hours of these professionals may not exceed thirty weekly hours (30). According to the municipal coordinator of the NASF, as legislation of this institution establishes no more than 200 hours a week as the workload of professionals, the work was organized so that some professionals work twenty hours and others, forty hours, but without precise justification for choosing the physiotherapists and social workers to have the lower workloads.

As for the workload, it would be important to plan the distribution of hours in order to meet the needs of the territories, the time of displacement between the various CSF, the participation of professionals in the meetings of the FHS, discussion and construction of therapeutic projects, shared care, home visits, direct assistance to users in the territory along with the family health teams, as recommended by the NASF Guidelines (1).

The individual and fragmented work of the FHS was also mentioned as an obstacle that can be improved in the work of NASF physiotherapists.

Sometimes, they [FHS professionals] request support from NASF, but it is like we said, you do your part and I'll do mine. Then you do your groups and we do what is our work, this is not an integrated activity. (P2)

The creation of groups is based on my demand, the way I want to do. I have teams that have this opening to talk, there is an opening for sharing opinions, but provided does not bring more work for the family health team. (P3)

These statements show that there is a mismatch between what is advocated in the NASF guidelines and what actually happens in the studied centers. The NASF work process assumes that its professionals are responsible for a territory together with the family health teams. Thus, the intervention must be interdisciplinary, with knowledge exchange, training and mutual accountability with discussion of cases and prior negotiation between professionals to plan the activities to be developed. Furthermore, the actions undertaken in the territories should be articulated with the family health teams, through health projects in the territory, planning, support groups, educational work and in partnership with other sectors, such as schools, churches, etc. (1).

Andrade et al. (31) also observed, when analyzing the flaws in the implementation of NASF in the Mid-West of Santa Catarina, the absence of sharing responsibilities, interdisciplinary work and a shared therapeutic work.

Lancman et al. (32) investigated the characteristics of the organization, working conditions and subjective experiences related to the work of two NASF in 
São Paulo and found that the FHS and the NASF have different labor organizations and demands. While the FHS is more focused on direct contact with users, with demands that require quick and urgent solutions, NASF prioritizes discussion and shared reflection, time-consuming activities that depend on the availability of all involved. These points show that there is a mismatch between the need to meet the demands and the new logic of work proposed by NASF.

Another factor that can hinder the collective planning of actions is the migration of professionals between the different FHS, because NASF is responsible for nine to 12 FHS. This displacement between the different teams can lead to losses in the creation of links with the community and the continuity of actions (33).

For physiotherapists of NASF, the weakness in vocational training related to public health also represents a difficulty.

In fact, I was unaware of what was NASF when I applied for the selection process. I had training, but on health promotion. But very different from what is seen and what is health promotion within the unit. (P1)

I think Physiotherapy courses have a weak education in public health because the professional has been inserted only in recent times. In the logic of NASF, created in 2008, only five years, here [in the municipality], it is going to be the fourth year. So, it's a short time yet. We had no good training on or familiarity with the FHS. (P3)

Ceccim and Feuerwerker (34) argue that the training of health professionals should include the study beyond the diagnosis, treatment, care, etiology and prophylaxis of diseases and disorders. It should seek to develop conditions for meeting the health needs of individuals and populations, the management and social control.

It is also necessary to develop interdisciplinary practices during the training, so that different knowledge and practices are presented in the process of creating bonds between students and a given professional identity (35).

The SUS and the FHS demand professionals that have clear limits of performance, with construction skills and maintenance of link, hosting, qualification and production of knowledge with a view to promote actions alert to new and complex health needs of the population (36).
In this logic, physical therapy courses should be structured on the principles of the SUS and the health needs of the population. The professional responsibility includes, besides the tertiary level, the primary and secondary levels of health care. The training of physiotherapists, therefore, should approach practices of health promotion and public health, extending the possibilities of action for the determinants and conditions of the health-disease process (37).

Initiatives from the Ministries of Health and Education, including the Education Program for Working for Health (PET-Health) and the Pro-Health, have played an important role with regard to the reorientation of vocational training for the SUS. These tools represent a possibility to carry out the principle of indivisibility of teaching, research and outreach, besides providing ta he most effective interrelation between the fields of healthcare practice and the university. Olive et al. (38) reported the experience of PET-Health deployment at the Federal University of Mato Grosso do Sul, where physiotherapy students were inserted, and concluded that the program represented a necessary tool to sensitize the university and health services and that students involved were able to incorporate social, technical and scientific changes in their academic life.

In this sense, vocational training covering the theoretical background and practice on public health and specifically the theory of NASF, as the experience in this context and teamwork, represent a possibility of addressing some of the existing obstacles to the work of physiotherapists in this space and the lack of dialogue and shared planning in the team.

\section{Conclusion}

The results of this study indicate that the performance of physiotherapists in the studied NASF takes place through collective and individual actions, particularly meeting the demands and need for rehabilitation of the population. Among these, group assistance, home visits and educational activities on health and disease prevention stand out. From this perspective, they meet NASF Guidelines with regard to the actions directed to promotion, prevention and rehabilitation of individuals and of the community. It is noteworthy, however, the need to strengthen the matrix support, the central principle of the proposal of NASF, the interdisciplinary and the collective 
agreement between the FHS team, NASF and management to support the consolidation of primary care in Brazil, expanding its scope and solvability.

The lack of training to work on NASF, the structural and organizational impediments such as lack of resources and inadequate physical infrastructure, insufficient workload, individual or disjointed work of the FHS, and the flaws in the training on public health were indicated as the main difficulties to develop the work in the centers.

It is necessary to reflect that in the face of the adversity encountered to develop the work in NASF, shared planning between FHS, NASF and management is important, to define the priority actions to be developed, meet the health needs of the territory, and ensure the basic conditions for the smooth progress of work of the NASF teams. Moreover, it is evident that besides rehabilitation, the physiotherapists inserted in primary care develop an interdisciplinary work based on the health reality of the place and the knowledge of the territory. However, intersectoral and community participation need to be further explored in the work that these professional carry out.

It is in this context that vocational training plays a central role with regard to the development of skills and abilities to act in accordance with the principles of SUS. In this sense, the study of SUS, of territories, experiences and practices in interdisciplinary teams in primary care must be ensured. This way, students will be able to perceive themselves as future SUS professionals, a fundamental step for the success of NASF. Furthermore, continuing education emerges as one of the effective strategies to qualify the service of physiotherapists and to overcome the weaknesses experienced during the training process to work in the National Health System, specifically in Primary Care. However, this discussion must not stop here. Further research on the subject is encouraged, since the role of the physiotherapists in PC and especially in NASF is recent and still presents uncertainties as to its object and still faces difficulties.

\section{References}

1. Brasil. Ministério da Saúde. Secretaria de Atenção à Saúde. Departamento de Atenção Básica. Diretrizes do NASF: núcleo de apoio à saúde da família. Brasília: Ministério da Saúde; 2009.
2. Barbosa EG, Ferreira DLS, Furbino SAR, Ribeiro EEN. Experiência da Fisioterapia no Núcleo de Apoio à Saúde da Família em Governador Valadares, MG. Fisioter Mov. 2010;23(2):323-30.

3. Novais BKLO, Brito GEG. Percepções sobre o trabalho do fisioterapeuta na atenção primária. Rev APS. 2011;14(4):424-34.

4. Dibai Filho AV, Aveiro MC. Atuação dos fisioterapeutas dos núcleos de apoio à saúde da família entre idosos do município de Arapiraca-AL, Brasil. Rev Bras Promoç Saúde. 2012;25(4):397-404.

5. Nascimento RG, Oliveira JSS, Ferreira LS, Santos ZNL, Cardoso RO. Fisioterapia gerontológica na atenção primária à saúde: uma experiência na região norte. Revista Ciência \& Saúde. 2013;6(3):222-8.

6. Miranda FAC. Fisioterapia na Atenção Básica: uma proposta de apoio. Florianópolis. Dissertação (Mestrado em Saúde Coletiva) - Centro de Ciência da Saúde, Universidade Federal de Santa Catarina; 2011.

7. Souza MCD, Bomfim AS, Souza JN, Franco TB. Fisioterapia e Núcleo de Apoio à Saúde da Família: conhecimento, ferramentas e desafios. Mundo Saúde. 2013;37(2):176-84.

8. Neves LMT, Aciole GG. Desafios da integralidade: revisitando as concepções sobre o papel do fisioterapeuta na equipe de Saúde da Família. Interface. 2011;15(37):551-64.

9. Minayo MCS. O desafio do conhecimento: pesquisa qualitativa em saúde. 13th ed. São Paulo: Hucitec; 2013.

10. Badaró AFV, Guilhem D. Perfil sociodemográfico e profissional de fisioterapeutas e origem das suas concepções sobre ética. Fisioter Mov. 2011;24(3):445-54.

11. Naves CR, Brick VS. Análise quantitativa e qualitativa do nível de conhecimento dos alunos do curso de fisioterapia sobre a atuação do fisioterapeuta em saúde pública. Ciênc Saúde Coletiva. 2011;16(Supl. 1): 1525-34.

12. Formiga NFB, Ribeiro KSQS. Inserção do fisioterapeuta na Atenção Básica: uma analogia entre experiências acadêmicas e a proposta dos Núcleos de Apoio à Saúde da Família (NASF). R Bras Ci Saúde. 2012;16(2):113-22. 
13. Brasil. Ministério da Saúde. Secretária de Atenção à Saúde. Política Nacional de Humanização. Cadernos HumanizaSUS. Brasília; 2010.

14. Portes LH, Caldas MAJ, Paula LT, Freitas MS. Atuação do fisioterapeuta na Atenção Básica à Saúde: uma revisão da literatura brasileira. Rev APS. 2011;14(1):111-9.

15. Chapecó. Lei Complementar n. 402, de 30 de abril de 2010. Dispõe sobre a criação da função pública de agente do NASF e dá outras providências. Chapecó: Câmara de Vereadores, 2010 [cited 2012 Mar 22]. Available from: https://tinyurl.com/jwkvfk6

16. Baena CP, Soares MCF. Subsídios reunidos junto à equipe de saúde para a inserção da fisioterapia na Estratégia Saúde da Família. Fisioter Mov. 2012;25(2):419-31.

17. Gonçalves M. Contribuições da fisioterapia/exercício físico para pacientes idosos atendidos na Estratégia Saúde da Família (ESF). Ensaios e Ciência: Ciências Biológicas, Agrárias e da Saúde. 2011;15(1):243-60.

18. Medeiros PA, Pivetta HMF, Mayer MS. Contribuições da visita domiciliar na formação em fisioterapia. Trab Educ Saúde. 2012;10(3):407-26.

19. Ministério da Saúde (Brasil). Portaria n. 971, de 3 de maio de 2006. Aprova a Política Nacional de Práticas Integrativas e Complementares (PNPIC) no Sistema Único de Saúde [cited 2014 Mar 13]. Vailable from: https://tinyurl.com/m7uhe4h

20. Ischkanian PC, Pelicioni MCF. Desafios das práticas integrativas e complementares no SUS visando a promoção da saúde. Rev Bras Crescimento Desenvolv Hum. 2012;22(1):233-8.

21. Tesser CD, Barros NF. Medicalização social e medicina alternativa e complementar: pluralização terapêutica do Sistema Único de Saúde. Rev Saúde Pública. 2008;42(5):914-20.

22. Brasil. Ministério da Saúde. Secretaria de Atenção à Saúde. Departamento de Atenção Básica. Coordenação-Geral de Atenção Domiciliar. Caderno de atenção domiciliar, vol 2. Brasília; 2012.

23. Brasil. Ministério da Saúde. Portaria n. 963, de 27 de maio de 2013. Redefine a Atenção Domiciliar no âmbito do Sistema Único de Saúde (SUS). Brasília: Diário Oficial da União 28 maio 2013; n. 101, Seção I, p. 30.
24. Pinafo E, Nunes EFPA, González AD, Garanhani ML. Relações entre concepções e práticas de educação em saúde na visão de uma equipe de saúde da família. Trab Educ Saúde. 2011;9(2):201-21.

25. Davini MC. Enfoques, problemas e perspectivas na educação permanente dos recursos humanos de saúde. In: Brasil. Ministério da Saúde. Política Nacional de Educação Permanente em Saúde. Brasília: Ministério da Saúde; 2009. p. 39-63.

26. Sampaio J et al. O NASF como dispositivo de Gestão: limites e possibilidades. Rev Bras Ciênc Saúde. 2012;16(3):317-24.

27. Reis F, Vieira ACVC. Perspectivas dos terapeutas ocupacionais sobre sua inserção nos Núcleos de Apoio à Saúde da Família (NASF) de Fortaleza, CE. Cad Ter Ocup. 2013;21(2):351-60.

28. Ministério da Saúde (Brasil). Portaria n. 2.488, de 21 de outubro de 2011. Aprova a Política Nacional de Atenção Básica, estabelecendo a revisão de diretrizes e normas para a organização da Atenção Básica, para a Estratégia Saúde da Família (ESF) e o Programa de Agentes Comunitários de Saúde (PACS) [portaria na internet]. Brasília, 2011 [cited 2014 Mar 10]. Available from: https://tinyurl.com/h2ma9v8.

29. Oliveira PRS, Reis F, Arruda CAM, Vieira ACVC, Tófoli LF. Novos olhares, novos desafios: vivências dos Núcleos de Apoio à Saúde da Família em Fortaleza - CE. Cadernos ES. 2012;6(1):54-64.

30. Brasil. Lei n. 8.856, de $1^{\circ}$ de março de 1994. Fixa a Jornada de Trabalho dos Profissionais Fisioterapeuta e Terapeuta Ocupacional [cited 2014 Mar 20]. Disponível em: https://tinyurl.com/nyy9tb5.

31. Andrade LMB, Quandt FL, Campos DA, Delziovo CR, Coelho EBS, Moretti-Pires RO. Análise da implantação dos Núcleos de Apoio à Saúde da Família no interior de Santa Catarina. Sal \& Transf Soc. 2012;3(1):18-31.

32. Lancman S, Gonçalves RMA, Cordone NG, Barros JO. Estudo do trabalho e do trabalhar no Núcleo de Apoio à Saúde da Família. Rev Saúde Pública. 2013;47(5):968-75.

33. Baratieri T, Marcon SS. Longitudinalidade no trabalho do enfermeiro: identificando dificuldades e perspectivas de transformação. Texto Contexto - Enferm. 2012;21(3):549-57. 
34. Ceccim RB, Feuerwerker LCM. O quadrilátero da formação para a área da saúde: ensino, gestão, atenção e controle social. PHYSIS: Rev Saúde Coletiva. 2004;14(1):41- 65 .

35. Uchimura KY, Bosi MLM. Habilidades e competências entre trabalhadores da Estratégia Saúde da Família. Interface. 2012;16(40):149-60.

36. Costa RKS, Miranda FAN. Formação profissional no SUS: oportunidades de mudanças na perspectiva da Estratégia de Saúde da Família. Trab Educ Saúde. 2008;6(3):503-18.

37. Bispo Júnior JP. Formação em fisioterapia no Brasil: reflexões sobre a expansão do ensino e os modelos de formação. Hist Ciênc Saúde-Manguinhos. 2009;16(3):655-68.
38. Oliveira ML, Alves Filho HL, Coelho TC, Benetti CN, Totti MFP, Inagaki PM et al. PET-Saúde: (In)formar e fazer como processo de aprendizagem em serviços de saúde. Rev Bras Educ Med. 2012;36(1) (supl.2):105-11.

Received in $12 / 11 / 2015$ Recebido em 11/12/2015

Approved in 03/10/2017 Aprovado em 10/03/2017 